\title{
Public Perception of Probity (Luke 3:12-14) in Public Service and Its Impact on Sustainable Development in Benue State
}

\author{
Dominic Shimawua \\ Department of Public Administration, Veritas University (the Catholic University of Nigeria), Abuja, Nigeria
}

Email address:

dshimawua@gmail.com

\section{To cite this article:}

Dominic Shimawua. Public Perception of Probity (Luke 3:12-14) in Public Service and Its Impact on Sustainable Development in Benue State. Humanities and Social Sciences. Vol. 4, No. 6, 2016, pp. 154-160. doi: 10.11648/j.hss.20160406.14

Received: September 19, 2016; Accepted: October 2, 2016; Published: November 14, 2016

\begin{abstract}
Probity as an obligation to public servants is a tenet that must be adhered to for a sustainable development to ensue. Apparently, unlike the private sector, the public sector is bound to be accountable to the public and subject to audit and political scrutiny. Therefore, standards of acceptable conduct cannot be compromised; and as such, public service needs to demonstrate probity in all its endeavors. The study examined the public perception of probity (Luke 3:12-14) in Public Service and its impact on Sustainable Development in Benue State. The study adopted the descriptive survey design. The target population of study was Civil Servants who constitute bulk of the Public Service in Benue State. Sample size of 378 from the population was drawn using sample size table; and Random sampling technique was used in selecting the subjects for the study. Mean and standard deviation will be used in achieving the research objectives for the study and Chi-Square in testing the hypotheses formulated at 0.05 significance level. The study discovered that the public perceived probity to be complete honesty, truthfulness, reliability, good, honest, moral excellence, integrity, rectitude, uprightness and conscientiousness of public servants, which has positive impact on sustainable development. It was therefore, recommended that governments and stakeholders should encourage public servants to avoid corrupt practices that demonstrate lack of probity in public service. Moreover, it was also recommended that the church should do more in sermonizing its members who are mostly public servants on scriptures such as Luke 3:12-14 and other similar scriptures to enforce probity in public service in Benue State.
\end{abstract}

Keywords: Public Service, Probity in Public Service, Sustainable Development, Scriptural Perspective on Probity

\section{Introduction}

Probity as an obligation to public servants is a tenet that must be adhered to for a sustainable development to ensue. Apparently, unlike the private sector, the public sector is bound to be accountable to the public and subject to audit and political scrutiny. Therefore, standards of acceptable conduct cannot be compromised; and as such, public service needs to demonstrate probity in all its endeavors.

The public service (Ministries, Departments and Agencies) has always been the tool available to the Nigeria government for the implementation of development goals and objective. It is seen as the pivot for growth of African economies. It is responsible for the creation of an appropriate conducive environment in which all sectors of the economy can operate maximally. The public service is expected to play a catalytic role in the economic sector by providing the enabling policies for all the sector of the economy (Junaidu \& Aminu 63).

Incidentally, people have always erred in public service though; accountability is the watchword of public service as the hallmark of modern democratic governance. Fundamentally, democracy can only remain a paper procedure if leaders or public servants cannot be held accountable in the public for the err-ways or acts and omissions, for their decisions, policies, and expenditures. Obazee (5), Sylvester (1) and Junaidu and Aminu (63) asserted that the general public is increasingly requiring public officers to be accountable by demonstrating effective use of public assets and funds in the delivery of services and pursuit of government objectives. 


\section{Statement of the Problem}

Public service is an appendage of democratic inclusion and participation and as such the Nigeria's public service is strategically positioned to manage the nation's resources for service delivery to the people. Moreover, in order to achieve service delivery to the Nigerian populace efficiently, there must be probity in public service. Apparently, in the struggles to maintain probity in public service, policy makers have designed code of conducts or bylaws to guide public servants and ensure probity in the public service. Importantly, the church as a strong agent of social control and socialization has played its part in the struggles to ensure probity in public service among its members or adherents using biblical teachings to achieve this. In essence, the injunction of Luke $3: 12-14$ is used in admonishing public servants who are Christians to maintain probity in their services to the public by being accountable, transparent and maintaining equity.

Despite government and stakeholders' struggles to ensure probity in public service, researchers such as Osezua and Julius (419) lamented that the public service has however, been associated with poor or total absence of probity and accountability, with the overall effects of default in service rendering though; the essence of good governance is to establish a room for public probity, accountability and transparency so as to ensure the principles of justice, equity and fairness within the constitutional jurisdiction. Consequently, if this is allowed to continue, in the near future, the consequences cannot be foretold. Therefore, this study investigates public perceptions on whether Luke 3:1214 has any impact on probity in public service for sustainable development in Benue State.

\subsection{Objectives of the Study}

The objective of this study is to investigate Public Perception of Probity (Luke 3:12-14) in Public Service and its Impact on Sustainable Development in Benue State. Specifically, the study sought to:

(1) Ascertain the public perception of probity in public service and its impact on sustainable development in Benue State

(2) Determine the factors hampering probity in public service and its impact on sustainable development in Benue State

(3) Find out strategies for the improvement of probity in public service for sustainable development in Benue State

\subsection{Research Hypotheses}

(1) Probity in public service has not significantly impacted on sustainable development in Benue State

(2) There are no significant factors hampering probity in public service and its impact on sustainable development in Benue State

(3) There are no significant strategies for the improvement of probity in public service for sustainable development in Benue State

\section{Literature Review}

\subsection{Public Service}

Public service is a potential tool for the development of the society and most significantly, when probity is the watchword in public service; accountability, transparence, equity and justice are ensued. Maikudi and Mikail (85) asserted that the essence of good governance is to establish a room for public probity, accountability and transparency so as to ensure the principles of justice, equity and fairness within the constitutional jurisdiction. However, it is the role of democratic government to accommodate the above principles for the betterment of its citizens as well as to foster national development.

The term public service is broader and more inclusive. The first definition is that public service refers to government parastatals, which are the operational arm of government ministries as well as the ministries, departments and agencies (MDA). The Public Service on the other hand, in addition to the Civil Service, encompasses the Armed Forces, the Judiciary, the Police, Government Institutions, Parastatals; Government owned Companies and Statutory Agencies (Fagbemi 6).

Apparently, Public service comprises of the three arms of government, the executive, legislative and judiciary, collectively rendering services to the Nigerian public. Based on this ideology, public servants therefore are in turn the persons in the employment of all the said three arms of government, whether they are senior and junior cadres including the scheduled officers and the political office holders in the government.

Osezua and Julius (419) observed that Nigeria's public service is strategically positioned to manage the nation's resources for service delivery to the people. The service has however, been associated with poor or total absence of accountability, with the overall effects of default in service rendering. Nigeria's public service for now is the largest employer of labor as well as the largest provider of services in Nigeria. This situation in essence represents the feature and level of the nation's present economic development where government investment was concentrated on the establishment of public enterprises.

Consequently, the public service of any nation that is run without probity will be in dearth of sustainable development and be precipitated into doom. Therefore, probity is the only potent ingredient that will refine

\subsection{Probity in Public Service}

Quick (2) defined probity as meaning good, honest, moral excellence, integrity, rectitude, uprightness, conscientiousness. When used in a contractual context it means good process. Probity provides check on public servants as the affairs of government are conducted in the open. The people have the prerogative of information on public matters in the system that abhors information hoarding by a few. 
Probity in public service entails complete honesty, truthfulness and reliability of public servants in public service. Essentially, probity encompasses openness without deceit, secrecy, shadiness and virtues of good stewardship, accountability and above all, trust. The intercourse between probity and public service to produce sustainable development is inseparable.

Apparently, probity in public service has to do with public accountability and transparency, which are veritable indices of good governance in democratic era. Maikudi and Mikail (85) therefore, noted that the basic assumption in democratic system is that a government would perform prudently and judiciously in public financial management for the attainment of equity, transparency and public accountability for the betterment of the entire citizens.

There have been assumptions that the duties and trust reposed on these public officers were not efficiently and effectively performed. More so, there has been total disregard for accountability on the part of public enterprises over the years and that a lot of public enterprises do not bother to produce promptly their annual reports and audited financial statements due to inefficiency, negligence, and maladministration (Onochie, 2002 and Sylvester, 2013).

Incidentally, unlike the private sector, the public service is accountable to the public and subject to audit and political scrutiny as standards of acceptable conduct cannot be compromised. The public service therefore, needs to demonstrate probity in all spheres.

Probity in public service should ensure the following:

- Avoidance of corrupt practices

- Improvements in public service integrity through organizational and attitudinal change

- Reassurance to the public and those wishing to do business with the public service, that the process and outcome can be trusted

- Provision of an objective and independent view on the fairness of the process discharge of duties

- The avoidance of conflicts of interest problems, and

- Minimization of potential for litigation

\subsection{Sustainable Development}

The term or concept development has been defined by almost every author in a different way. Incidentally, development is not purely an economic phenomenon but rather a multi-dimensional process involving reorganization and reorientation of entire economic and social system. Researchers like Leinbach (2016) believe that development can be seen in two folds, as a state or condition (static) and as a process or course of change (dynamic). Development as the process of improving the quality of all human lives or otherwise must have a marriage to sustainability for it to survive and that is sustainable development.

Although many definitions abound, the most often used definition of sustainable development is that proposed by the Brundtland Commission. The Brundtland Commission defines sustainable development as the ability to make development sustainable - to ensure that it meets the needs of the present without compromising the ability of future generations to meet their own needs. This is surely the standard definition when judged by its widespread use and frequency of citation (Dernbach 3, Dernbach, Sustainable 247, Cerin 210, Stoddart 23 \& Emas 2).

Apparently, the overall goal of sustainable development is the long-term stability of the economy and environment; this is only achievable through probity in public service and by the integration and acknowledgement of economic, environmental, and social concerns throughout the decision making process.

\subsection{Scriptural Perspectives on Probity (Luke 3:12-14) for Sustainable Development}

Then came also publicans to be baptized, and said unto him, Master, what shall we do? And he said unto them, Exact no more than that which is appointed you. And the soldiers likewise demanded of him, saying, and what shall we do? And he said unto them, do violence to no man neither accuse any falsely; and be content with your wages (Luke 3:12-14, $\mathrm{KJV}$ ). The $\tau \varepsilon \lambda \tilde{\omega} v \alpha$, the Latin publicani (whence our rendering), were men who collected the Roman taxes or imposts. These imperial taxes, the most painful and ever present reminder to the Jew of his subject and dependent position, were in the first instance leased out to jobbers and speculators of the equestrian order; these were properly the publican (Bible Hub 1).

Obviously, the publicans (task collectors and soldiers) as presented by Luke are to be commended for their selfassessment and discovery to know that they needed baptism, which was to change from their old ways to new ways. The publicans came to terms with the knowledge of the need for probity in the discharge of their public duties to the public. Apparently, this gives us a light into what is ought to be done by the Nigerian public servants so as to ensure that probity ensues in public service in Benue State and Nigeria at large.

Moreover, an important objective was raised by the publicans including soldiers, "What shall we do?" It behooved on these public servants to understand that it was an obligation for them to do what was lawful and just as was summed up in the directive achieve:

(1) Exact no more than that which is appointed you

(2) Do violence to no man

(3) Neither accuse any falsely; and

(4) Be content with your wages

Essentially, these were the scriptural principal principles for the maintenance of probity in public service, which is just as meaning:

(1) Keep away from your habitual sin of extravagant greed and cruel exactions; or stop cheating and meddling for which Zacchaeus promised fourfold restoration

(2) Do not assassinate, murder, kill, kidnap, blackmail or harm political opponent because you want to win elections at all cost

(3) Avoidance of situation where government and stakeholders know perpetrators of certain crimes but allow the police to arrest innocent people and accuse 
them of committing the crimes

(4) Your salary or payment should be enough for you so that you do not demand, or take, from the poor

In this way, it is possible that probity may be ensured in the public service in Benue State and the entire country's public service to ensure a sustainable development. More so, the scriptural injunction of Luke 3:12-14 seems in this wise, a potential tool for the inculcation of probity in public service as most of the public servants are affiliated to Christianity, which promotes the propagation of this scripture.

\section{Methodology}

The study adopted a survey design, which is the type of design that enables the researcher to collect data from a group of people through objectivenaire, interview or observation techniques for the purpose of analysis and subsequent interpretation. It is used to critically analyze the situation based on information (Nworgu 10).

\subsection{Population and Sample}

The target population of the study was state civil servants who form greater part of public service, in Benue State. There are 20,147 State Civil Servants in Benue State (Benue State Civil Service Commission 16). The sample size of 378 out of the population of 20,147 was drawn using the sample size table (Emaikwu 105). The random sampling technique was adopted in selecting the subjects.

\subsection{Instrument for Data Collection}

The instrument used for data collection was Objectivenaire constructed by the researcher. Section A of the objectivenaire contained respondents' bio-data, which included sex and ministry. Section B consisted of 4 variables of probity in public service and its impact on sustainable development. Section $\mathrm{C}$ consisted of 6 variables of factors hampering probity in public service and its impact on sustainable development and Section D consisted of 5 variables of strategies for the improvement of probity in public service for sustainable development in Benue state. The 15 item objectivenaire was structured on a 4-point rating scale and respondents were asked to respond by ticking the correct or applicable responses (SA) strongly agree, (A) agree, (D) disagree and (SD) strongly disagree.

\subsection{Method of Data Collection and Analysis}

Apparently, copies of the objectivenaire were administered to the respondents in the study area with the aid of two research assistants, who administered and retrieved the objectivenaire from the respondents. These research assistants were asked to administer and retrieve the objectivenaire through personal contact to avoid delays associated with mailing and multiple filling. Data were analyzed using mean and standard deviations to achieve the research objectives while Chi-Square was used in testing the hypotheses formulated at 0.05 significance level.

\subsection{Achieving the Research Objectives}

Data was collected using 4 point rating scale instrument. Importantly, on each research objective, data were collected on related items in the instrument. The collected data were analyzed using mean and standard deviation. Apparently, any item of the instrument whose mean rating scores was 2.50 and above was considered significant and any item with the mean rating scores below 2.50 was not considered significant.

(1) Research Objective 1

What is the public perception of probity in public service and its impact on sustainable development in Benue State?

To achieve the objective, data were collected on public perception of probity in public service and its impact on sustainable development in Benue State. The collected data were analyzed and presented in Table 1.

Table 1. Descriptive Statistics of Public Perception of Probity in Public Service.

\begin{tabular}{llll}
\hline Descriptive Statistics & N & Mean & Std. Deviation \\
\hline & 378 & 3.0899 & 1.07410 \\
\hline $\begin{array}{l}\text { Complete honesty, truthfulness and reliability of public servants in public service impacts positively on } \\
\text { sustainable development }\end{array}$ & 378 & 3.5000 & .83444 \\
$\begin{array}{l}\text { Public servants' openness without deceit, secrecy and shadiness helps in bringing sustainable development } \\
\text { Virtues of good stewardship and accountability of public servants can help government apparatus to work } \\
\text { efficiently to ensure sustainable development }\end{array}$ & 378 & 3.1032 & 1.00789 \\
$\begin{array}{l}\text { Audit and political scrutiny as standards of acceptable conduct in public service brings probity and ensures } \\
\text { sustainable development }\end{array}$ & 378 & 2.9233 & .62820 \\
Valid N (listwise) & 378 & \\
\hline
\end{tabular}

From Table 1, it can be seen that the mean rating scores of all the items are above 2.50. This means that complete honesty, truthfulness and reliability of public servants in public service impacts positively on sustainable development, public servants' openness without deceit, secrecy and shadiness helps in bringing sustainable development, virtues of good stewardship and accountability of public servants can help government apparatus to work efficiently to ensure sustainable development and audit and political scrutiny as standards of acceptable conduct in public service brings probity and ensures sustainable development indicates the public perception of probity in public service and its impact on sustainable development in Benue State.

(2) Research Objective 2

What are the factors hampering probity in public service and its impact on sustainable development in Benue State? 
To achieve the objective, data on public perception of factors hampering probity in public service and its impact on sustainable development in Benue State were collected, analyzed and presented in Table 2.

Table 2. Descriptive Statistics of Public Perception on Factors Hampering Probity in Public Service.

\begin{tabular}{|c|c|c|c|}
\hline \multicolumn{4}{|l|}{ Descriptive Statistics } \\
\hline & $\mathbf{N}$ & Mean & Std. Deviation \\
\hline Lack of avoidance of corrupt practices & 378 & 3.5767 & .82126 \\
\hline Lack of improvements in public service integrity through organizational and attitudinal change & 378 & 3.0159 & .81417 \\
\hline $\begin{array}{l}\text { Lack of reassurance to the public and those wishing to do business with the public service, that the process } \\
\text { and outcome can be trusted }\end{array}$ & 378 & 2.8122 & .96856 \\
\hline No provision of an objective and independent view on the fairness of the process discharge of duties & 378 & 3.6852 & .65458 \\
\hline None avoidance of conflicts of interest problems & 378 & 3.4524 & .92939 \\
\hline Valid N (listwise) & 378 & & \\
\hline
\end{tabular}

From Table 2, it can also be seen that the mean rating scores of all the items is above 2.50, which implies that lack of avoidance of corrupt practices, lack of improvements in public service integrity through organizational and attitudinal change, lack of reassurance to the public and those wishing to do business with the public service, that the process and outcome can be trusted, no provision of an objective and independent view on the fairness of the process discharge of duties, none avoidance of conflicts of interest problems, and inability to minimize potential for litigation are the factors hampering probity in public service and its impact on sustainable development in Benue State.

(3) Research Objective 3

Are there strategies for the improvement of probity in public service for sustainable development in Benue State?

To achieve the objective, data were collected on public perception on strategies for improvement of probity in public service for sustainable development in Benue State, analyzed and presented in Table 3 .

Table 3. Descriptive Statistics of Public Perception Strategies for the Improvement of Probity in Public Service.

\begin{tabular}{|c|c|c|c|}
\hline \multicolumn{4}{|l|}{ Descriptive Statistics } \\
\hline & $\mathbf{N}$ & Mean & Std. Deviation \\
\hline Governments and stakeholders should encourage public servants to avoid corrupt practices & 378 & 3.5476 & .49839 \\
\hline There should be improvements in public service integrity through organizational and attitudinal change & 378 & 3.4259 & .85318 \\
\hline $\begin{array}{l}\text { There should be reassurance to the public and those wishing to do business with the public service, that the process } \\
\text { and outcome can be trusted }\end{array}$ & 378 & 3.2090 & .91624 \\
\hline There should be a provision of an objective and independent view on the fairness of the process discharge of duties & 378 & 2.7407 & .74026 \\
\hline There must be avoidance of conflicts of interests, and minimization of potential for litigation & 378 & 3.3333 & 1.02230 \\
\hline
\end{tabular}

Table 3 shows the mean rating scores of all the items above 2.50. Essentially, this implies that Governments and stakeholders should encourage public servants to avoid corrupt practices, improvements in public service integrity through organizational and attitudinal change, reassurance to the public and those wishing to do business with the public service, that the process and outcome can be trusted, provision of an objective and independent view on the fairness of the process discharge of duties and avoidance of conflicts of interests, and minimization of potential for litigation are the strategies for the improvement of probity in public service for sustainable development in Benue State.

\subsection{Research Hypotheses}

Hypotheses were formulated to test the significances in the study. The hypotheses were tested at 0.05 level of significance. Since Statistical Package for Social Sciences (SPSS) was used for this analysis, the 0.05 is compared with Asymp. Sig (computer calculated probability for decision taking) value denoted as $\mathrm{P}$. Therefore, if $\mathrm{P}$ was greater than 0.05 the hypothesis was not rejected.

(1) Hypotheses 1

Probity in public service has not significantly impacted on sustainable development in Benue State.

To test for Hypothesis 1, data were collected relating to the hypothesis. The collected data were analyzed and presented in Table 4.

Table 4. Chi-Square Test of Opinion of Respondents on Probity in Public Service and its Impact on Sustainable Development.

\begin{tabular}{|c|c|c|c|c|c|c|}
\hline & Observed N & Expected N & $\chi^{2}$ & df & Asymp. Sig & Remarks \\
\hline $\begin{array}{l}\text { Probity in public service has not significantly impacted on } \\
\text { sustainable development in Benue State }\end{array}$ & 35 & 189.0 & 250.963 & 1 & .000 & Significant \\
\hline $\begin{array}{l}\text { Probity in public service significantly impacts on sustainable } \\
\text { development in Benue State }\end{array}$ & 343 & 189.0 & & & & \\
\hline Total & 378 & & & & & \\
\hline
\end{tabular}


From Table 4, it can be seen that 35 with expected frequency of 189.0 respondents were of the opinion that probity in public service has not significantly impacted on sustainable development in Benue State while 343 with expected frequency of 189.0 respondents said that probity in public service has significantly impacted on sustainable development in Benue State. Testing for the difference, $\chi^{2}=$ 250.963 with $\mathrm{df}=1$ and had computer calculated probability for decision taking (Asymp. Sig.) $=.000=$ P. Since P is less than 0.05 (significance level) then the difference is statistically significant. The hypothesis is therefore rejected with the conclusion that probity in public service has significantly impacted on sustainable development in Benue State.

\section{(2) Hypotheses 2}

There are no significant factors hampering probity in public service and its impact on sustainable development in Benue State.

To test for Hypothesis 2, data were collected relating to the hypothesis. The collected data were analyzed and presented in Table 5.

Table 5. Chi-Square Test of Opinion of Respondents on Factors Hampering Probity in Public Service and its Impact on Sustainable Development.

\begin{tabular}{|c|c|c|c|c|c|c|}
\hline & Observed N & Expected N & $\chi^{2}$ & df & Asymp. Sig & Remarks \\
\hline $\begin{array}{l}\text { There are no significant factors hampering probity in public } \\
\text { service and its impact on sustainable development }\end{array}$ & 15 & 189.0 & 320.381 & 1 & .000 & Significant \\
\hline $\begin{array}{l}\text { There are significant factors hampering probity in public service } \\
\text { and its impact on sustainable development }\end{array}$ & 363 & 189.0 & & & & \\
\hline Total & 378 & & & & & \\
\hline
\end{tabular}

Table 5 shows 15 respondents with expected frequency of 189.0 who were of the opinion that there are no significant factors hampering probity in public service and its impact on sustainable development in Benue State while 363 with expected frequency of 189.0 said that there are significant factors hampering probity in public service and its impact on sustainable development in Benue State. Testing for the difference, $\chi^{2}=320.381$ with $\mathrm{df}=1$ and had computer calculated probability for decision taking (Asymp. Sig.) $=.000=$ P. Since P is less than 0.05 (significance level) then the difference is statistically significant. Therefore, the hypothesis is rejected with the conclusion that there are significant factors hampering probity in public service and its impact on sustainable development in Benue State.

(3) Hypotheses 3

There are no significant strategies for the improvement of probity in public service for sustainable development in Benue State

To test for Hypothesis 3, data were collected relating to the hypothesis. The collected data were analyzed and presented in Table 6.

Table 6. Chi-Square Test of Opinion of Respondents on Strategies for the Improvement of Probity in Public Service for Sustainable Development.

\begin{tabular}{|c|c|c|c|c|c|c|}
\hline & Observed N & Expected N & $\chi^{2}$ & df & Asymp. Sig & Remarks \\
\hline $\begin{array}{l}\text { There are no significant strategies for the improvement of probity } \\
\text { in public service for sustainable development }\end{array}$ & 34 & 189.0 & 254.233 & 1 & .000 & Significant \\
\hline $\begin{array}{l}\text { There are significant strategies for the improvement of probity in } \\
\text { public service for sustainable development }\end{array}$ & 344 & 189.0 & & & & \\
\hline Total & 378 & & & & & \\
\hline
\end{tabular}

Table 6 shows 34 respondents with expected frequency of 189.0 who were of the opinion that there are no significant strategies for the improvement of probity in public service for sustainable development in Benue State while 344 with expected frequency of 189.0 said that there are significant strategies for the improvement of probity in public service for sustainable development in Benue State. Testing for the difference, $\chi^{2}=254.233$ with $\mathrm{df}=1$ and had computer calculated probability for decision taking (Asymp. Sig.) $=.000=$ P. Since P is less than 0.05 (significance level) then the difference is statistically significant. The hypothesis is rejected with the conclusion that there are significant strategies for the improvement of probity in public service for sustainable development in Benue State.

\section{Discussion of Findings}

(1) The findings of the study, based on the results in Table 1, showed that complete honesty, truthfulness and reliability of public servants in public service impacts positively on sustainable development, public servants' openness without deceit, secrecy and shadiness helps in bringing sustainable development, virtues of good stewardship and accountability of public servants can help government apparatus to work efficiently to ensure sustainable development and audit and political scrutiny as standards of acceptable conduct in public service brings probity and ensures sustainable development are the public perception of probity in public service and its impact on sustainable development in Benue State. The hypothesis was rejected with the conclusion that probity in public service has significantly impacted on sustainable development in Benue State.

(2) The finding of the study, based on the results in Table 2 , revealed that lack of avoidance of corrupt practices, lack of improvements in public service integrity through organizational and attitudinal change, lack of 
reassurance to the public and those wishing to do business with the public service, that the process and outcome can be trusted, no provision of an objective and independent view on the fairness of the process discharge of duties, none avoidance of conflicts of interest problems, and inability to minimize potential for litigation are the factors hampering probity in public service and its impact on sustainable development in Benue State. The hypothesis was rejected with the conclusion there are significant factors hampering probity in public service and its impact on sustainable development in Benue State.

(3) The findings from the study based on the results in Table 3, showed that governments and stakeholders should encouraging public servants to avoid corrupt practices, improvements in public service integrity through organizational and attitudinal change, reassurance to the public and those wishing to do business with the public service, that the process and outcome can be trusted, provision of an objective and independent view on the fairness of the process discharge of duties and avoidance of conflicts of interests, and minimization of potential for litigation are the strategies for the improvement of probity in public service for sustainable development in Benue State. The hypothesis was rejected with the conclusion that there are significant strategies for the improvement of probity in public service for sustainable development in Benue State.

\section{Conclusion}

The research was carried out and it was discovered that the public perceived probity to be complete honesty, truthfulness, reliability, good, honest, moral excellence, integrity, rectitude, uprightness and conscientiousness of public servants, which has positive impact on sustainable development. It was therefore, recommended that governments and stakeholders should encourage public servants to avoid corrupt practices that demonstrate lack of probity in public service. Moreover, it was also recommended that the church should do more in sermonizing its members who are mostly public servants on scriptures such as Luke 3:12-14 and other similar scriptures to enforce probity in public service in Benue State.

\section{References}

[1] Benue State Civil Service Commission. The population of state government civil servants by ministries - Government Gazette. Makurdi: Benue Government Printing and Publishing Company, 2015. Print.

[2] Bible Hub. Bible commentaries. Retrieved from http://biblehub.com/commentaries/ 2016.

[3] Cerin, Pontus. Bringing economic opportunity into line with environmental influence: A Discussion on the Coase theorem and the Porter and van der Linde hypothesis. Ecological Economics, 209-225, 2006. Print.

[4] Dernbach, John C. Sustainable development as a framework for national governance. Case Western Reserve Law Review, 19 (3), 1-103, 1998. Retrieved from

http://scholarlycommons.law.ase.edu/cgi/viewcontent.cgi?arti cle $=2248 \&$ context $=$ caselrev

[5] Dernbach, John C. Achieving sustainable development: The Centrality and multiple facets of integrated decision making. Indiana Journal of Global Legal Studies, 1 (1), 247-285, 2003. Print.

[6] Emaikwu, Sunday Oche. Fundamentals of research methods and statistics. Rev. Ed. Makurdi: Selfers Academic Press Limited, 2015. Print.

[7] Emas, Rachel. The Concept of Sustainable Development: Definition and Defining Principles. Florida: Florida International University Press, 2015. Print.

[8] Fagbemi, Ayodele. Introduction to public services. Lagos: The National Open University Press, 2015. Print.

[9] Junaidu, Bello Marshall and Aminu, Murtala. Public service in Nigeria- an overview of functions and code of conduct. Global Journal of Politics and Law Research, 3 (1), 61-69, 2015. Print.

[10] Leinbach, Thomas. The concept of development. Retrieved from

www.uky.edu/AS/Courses/GEO260/Powerpoint/Concept_of Development.ppt, 2016.

[11] Maikudi, Asma'u Sani and Mikail, Ibrahim Kawuley. Assessment of the role of public service reforms in promoting public accountability in Nigeria's democratic era (1999-2009). JORIND, 12 (1), 85-94, 2014. Print.

[12] Nworgu, Boniface Ginikanwa. Introduction to educational research. Ibadan: Longman Nigeria Publishers, 2006. Print.

[13] Obazee, Jim. Development in Public Sector Accounting and Reporting. A paper presented at a workshop organized by the Institute of Chartered Accountants of Nigeria on Public Sector Accounting, held at Sharon Ultimate Hotel, Abuja on June 14$15,2006$.

[14] Osezua, Ehiyamen and Julius, Faniran. The imperativeness of transparency and probity in Nigeria public Service. The Journal of International Social Research, 6 (27), 419-427, 2013. Print.

[15] Quick, Roger. Probity. Brisbane: Gardens Lawyers, 2003. Print.

[16] Stoddart, Hannah. (Ed). A Pocket guide to sustainable development governance. Westminster: Stakeholder Forum, 2011. Print.

[17] Sylvester, Feyi Akinbuli. An assessment of accountability in the public sector in Nigeria. Arabian Journal of Business and Management Review, 1, (3), 1-11, 2013. Print. 